\title{
Pengaruh Pajak Penjualan atas Barang Mewah dan Nilai Tukar Rupiah terhadap Penerimaan Pajak pada Kantor Pelayanan Pajak Pratama Makassar Barat
}

\author{
Sitti Mispa ${ }^{凶}$ \\ Sekolah Tinggi Ilmu Ekonomi Makassar Bongaya \\ DOI : https://doi.org/10.37531/ecotal.v2i2.26
}

\begin{abstract}
ABSTRAK
Hasil data variabel penelitian tersebut telah diuji asumsi klasik berupa asumsi normalitas, asumsi multikolonieritas dan asumsi heteroskedastisitasnya. Metode analisis data menggunakan teknik regresi linear berganda. Hasil penelitian menunjukkan bahwa secara simultan terdapat pengaruh antara PPnBM dan nilai tukar rupiah terhadap penerimaan pajak tahun 2015-2019 di KPP Pratama Makassar Barat. Sedangkan hasil analisis secara parsial didapat hasil bahwa PPnBM tidak berpengaruh signifikan terhadap penerimaan pajak dan nilai tukar rupiah berpengaruh secara signifikan terhadap penerimaan pajak.
\end{abstract}

\section{Kata Kunci :}

Pajak Penjualan, Barang Mewah, Nilai tukar rupiah, Penerimaan pajak.

\begin{abstract}
The results of the research variables have been tested for classical assumptions in the form of normality assumptions, multicollinearity assumptions and heteroscedasticity assumptions. Methods of data analysis using multiple linear regression techniques. The results luxury sales tax and exchange rate simultaneously on the tax revenue on year 2015-2019. at the West Makassar Pratama Tax Office and then Partial analysis variable luxury sales tax has no effect significantly with tax revenue while exchange rate has effect significantly to tax revenue.

Keywords : Luxury Sales Tax, Exchange Rate, Tax Revenue.
\end{abstract}

$\triangle$ Corresponding Author :

E-mail address: sitti_mispa@yahoo.co.id (Makassar, Sulawesi Selatan, Indonesia)

"Received 24 December 2020, Accepted 13 Januari 2021, Published 22 January 2021" 
Sitti Mispa ${ }^{\bowtie}$

Pengaruh Pajak Penjualan atas Barang Mewah dan Nilai Tukar Rupiah terhadap Penerimaan Pajak pada Kantor

Pelayanan Pajak Pratama Makassar Barat

DOI : https://doi.org/10.37531/ecotal.v2i2.26

\section{Pendahuluan}

Indonesia merupakan salah satu negara berkembang, dimana negara memerlukan pemasukan untuk membiayai pembangunan negara. Salah satu pemasukan negara yaitu berasal dari pajak (A.A Mirah Pradnya Paramita I Gusti Ayu Nyoman Budiasih, 2015). Pajak merupakan suatu sumber alternatif pembiayaan pembangunan yang diterapkan pada hampir seluruh negara didunia (Resmi, 2011). Sebagaimana kondisi tersebut, dapat kita lihat bahwa pendapatan negara di Indonesia juga didominasi oleh penerimaan pajak dibandingkan penerimaan negara bukan dari pajak. Karena banyaknya peran pajak, maka pajak senantiasa menjadi sumber penerimaan dalam negeri yang semakin diandalkan dalam membiayai pembangunan negara. Pajak merupakan salah satu penerimaan kas negara yang diperoleh dari masyarakat yang hanya dibebankan kepada mereka yang mempunyai kemampuan dalam membayar pajak. Pajak sangat berperan penting di Indonesia, karena sekitar 70\% (tujuh puluh persen) pengeluaran negara dibiayai oleh pajak. (www.pajak.go.id, 2013).

Pertumbuhan ekonomi yang negatif biasanya berpengaruh negatif terhadap penerimaan pajak. Atau dalam kata lain, terdapat pengaruh yang signifikan antara pertumbuhan ekonomi dengan peningkatan penerimaan pajak. Namun, menurut Wibowo (2014) penerimaan pajak sangat bergantung pada strategi-strategi internal yang diterapkan Direktorat Jenderal Pajak (DJP). Sejauh ini indikator yang digunakan untuk mengukur pertumbuhan ekonomi ialah Produk Domestik Bruto (PDB). Dimana PDB ini adalah jumlah seluruh barang dan jasa yang diproduksi suatu negara pada periode tertentu. PDB ini merupakan penjumlahan dari konsumsi, investasi, ekspor, netto yang terjadi di suatu negara, serta pengeluaran yang dilakukan oleh pemerintah. Pertumbuhan PDB yang positif seharusnya berpengaruh positif terhadap pertumbuhan penerimaan pajak dan berlaku sebaliknya. Pertumbuhan ekonomi Indonesia dapat didorong melalui berbagai faktor. Salah satu faktor dalam rangka mendorong perekonomian Indonesia adalah dengan masuknya WNA (Diky Budiman \& Septa Diana Nabella, 2020).

Negara Indonesia membutuhkan dana yang besar untuk membiayai segala kebutuhan dalam pelaksanaan pembangunan. Pelaksanaan pembangunan nasional membutuhkan dana yang terus meningkat dan anggaran yang memadai (Putu Vilia Puspitha \& Ni Luh Supadmi, 2018). Oleh karena itu pemerintah harus lebih bijaksana dalam mengelola setiap pendapatan. Dengan banyaknya pengeluaran utama negara yang harus direalisasikan dengan baik maka salah satu 
Sitti Mispa ${ }^{\bowtie}$

Pengaruh Pajak Penjualan atas Barang Mewah dan Nilai Tukar Rupiah terhadap Penerimaan Pajak pada Kantor

Pelayanan Pajak Pratama Makassar Barat

DOI : https://doi.org/10.37531/ecotal.v2i2.26

hal yang dibutuhkan dan sangat penting yaitu dengan adanya peran aktif dari masyarakat untuk memberikan iuran kepada negara dalam bentuk pajak sehingga semua keperluan pembangunan bisa dibiayai. Hal ini dikarenakan pajak merupakan andalan penerimaan bagi negara. Pajak memiliki fungsi dan berperan penting terhadap kesejahteraan negara dan masyarakat (Andri Gunawan \& I Made Sukartha, 2016). Segala biaya pembangunan dan pengembangan yang dilakukan oleh negara berasal dari masyarakat sendiri, bukan dari bantuan negara lain (Kadek Diah Puspareni, I Gusti Ayu Purnamawati \& Made Arie Wahyuni, 2017).

Penerimaan pajak masih menjadi sumber pendapatan negara. Lebih dari $80 \%$ pendapatan RI disumbang oleh pajak. Target penerimaan pajak tahun kemarin dipatok sebesar Rp 1.577,6 triliun di APBN 2019. Namun realisasi sementara hingga akhir tahun hanya mencapai Rp 1.332,1 triliun saja atau 84,4\%. Realisasi sementara penerimaan pajak tahun 2019 juga melorot dibanding tahun lalu. Pada 2018 capaian realisasi penerimaan pajak mencapai 92,2\% dari APBN. Penerimaan pajak tumbuh 1,4\% dibanding tahun sebelumnya. Angka pertumbuhan itu tentunya sangat minimalis jika dibandingkan dengan realisasi penerimaan pajak tahun lalu yang tumbuh hingga 14,1\%. (cnbcindonesia.com).

Realisasi Penerimaan pajak tahun 2015 hingga agustus 2019 dari data Kementerian Keuangan (Kemenkeu) mencatat realisasi penerimaan pajak hingga Agustus 2019 mencapai Rp 801,02 triliun atau 50,78\% dari target APBN 2019 yang sebesar Rp 1.577,56 triliun. Angka tersebut tumbuh 0,21\% dibandingkan tahun sebelumnya yang sebesar Rp 799,46 triliun. Secara rinci, realisasi pertumbuhan tertinggi terdapat pada Pajak Bumi dan Bangunan (PBB) dan pajak lainnya yang sebesar 52,41\% menjadi Rp 18,94 triliun. Sementara pertumbuhan lainnya terdapat pada pajak penghasilan (PPh) Migas yang sebesar 3,97\% (yoy) menjadi Rp 454,78 triliun. Namun, PPh Nonmigas mengalami pertumbuhan negatif 6,22\% (yoy) menjadi Rp 39,42 triliun. Selain itu, pertumbuhan negatif juga dialami pada Pajak Pertambahan Nilai (PPN) dan Pajak Penjualan Atas Barang Mewah (PPnBM) sebesar -6,36\% (yoy) menjadi Rp 288,01 triliun.

Tugas dan fungsi penerimaan pajak dijalankan oleh Direktorat Jenderal Pajak di bawah Kementerian Keuangan Republik Indonesia untuk pajak pusat dan Pemerintah Daerah untuk Pajak Daerah, Retribusi, Pajak Bumi dan Bangunan (PBB) khusus sektor pedesaan dan perkotaan. Jenis-jenis pajak yang dikelola oleh Direktorat Jenderal Pajak meliputi (1) Pajak 
Sitti Mispa ${ }^{\bowtie}$

Pengaruh Pajak Penjualan atas Barang Mewah dan Nilai Tukar Rupiah terhadap Penerimaan Pajak pada Kantor

Pelayanan Pajak Pratama Makassar Barat

DOI : https://doi.org/10.37531/ecotal.v2i2.26

Penghasilan (PPh), (2) Pajak Pertambahan Nilai (PPN) dan Penjualan Barang Mewah (PPnBM), (3) Pajak Bumi dan Bangunan (PBB) khusus sektor Pertambangan dan Perkebunan dan (4) pajak Bea Meterai (Kementerian Keuangan, 2015).

Dari empat jenis pajak yang dipungut pemerintah, Pajak Pertambahan Nilai dan Pajak Penjualan atas Barang Mewah (PPN \& PPnBM) serta Pajak Penghasilan Migas (PPh Migas) realisasinya mengecewakan. Capaian PPN \& PPnBM tahun 2019 tercatat hanya Rp 532,9 triliun atau 81,3\% dari APBN. Angka tersebut lebih rendah dibanding tahun lalu yang realisasinya mencapai Rp 537,3 triliun. Itu artinya realisasi sementara PPN \& PPnBM mengalami kontraksi 0,8\% dibanding tahun lalu. Sementara nilai tukar rupiah terhadap dollar AS rata-rata sejak awal tahun 2019 ada di Rp. 14.162, dengan asumsi APBN 2019 sebesar Rp.15.000. (cnbcindonesia.com). Sementara itu pendapatan Pajak Pertambahan Nilai (PPN) dan Pajak Penjualan atas Barang Mewah (PPnBM) ditargetkan sebesar Rp 685,8 triliun pada tahun 2020 atau naik 15,7\% dari outlook APBN 2019.

Target tersebut terdiri atas pendapatan PPN dan PPnBM Dalam Negeri (DN) senilai Rp 442,57 triliun. Ada pula PPN dan PPnBM impor yang ditargetkan sebesar Rp 243,17 triliun. Sementara jumlah PPN dan PPnBM lainnya hanya sebesar Rp 119,5 miliar. Lesunya penerimaan pajak diakibatkan oleh kombinasi sektor eksternal maupun internal. Dari sektor eksternal perang dagang yang terjadi antara AS dan China menjadi salah satu pemberat roda perekonomian global. Akibatnya volume perdagangan terkontraksi dan arus investasi menjadi melambat. Harga-harga komoditas seperti batu bara dan minyak mentah mengalami koreksi. Dampaknya juga dirasakan RI yang ekonominya masih bertumpu pada sektor komoditas. (cnbcindonesia.com).

Pajak Penjualan atas Barang Mewah (PPnBM) merupakan pajak yang dikenakan pada barang atau produk yang dipandang bukan sebagai barang kebutuhan pokok, dan dikonsumsi oleh masyarakat tertentu yang pada umumnya merupakan masyarakat berpenghasilan tinggi, juga barang yang dibeli untuk menunjukkan status, atau jika dikonsumsi dinilai dapat merusak kesehatan dan moral masyarakat Indonesia. Berdasarkan undang-undang yang berlaku di Indonesia, Pajak Penjualan Atas Barang Mewah (PPnBM) merupakan pajak yang dikenakan pada barang yang tergolong mewah yang dilakukan oleh produsen (pengusaha) untuk menghasilkan atau mengimpor barang tersebut dalam kegiatan usaha atau pekerjaannya. Sesuai dengan 
Sitti Mispa ${ }^{\bowtie}$

Pengaruh Pajak Penjualan atas Barang Mewah dan Nilai Tukar Rupiah terhadap Penerimaan Pajak pada Kantor Pelayanan Pajak Pratama Makassar Barat

DOI : https://doi.org/10.37531/ecotal.v2i2.26

Undang Undang No. 42 Tahun 2009 Pajak Penjualan Atas Barang Mewah dikenakan tarif serendah-rendahnya 10\% (sepuluh persen) dan paling tinggi 200\% (dua ratus persen). Perbedaan kelompok tarif tersebut didasarkan pada pengelompokan Barang Kena Pajak yang Tergolong Mewah yang atas pengenaanya dikenakan juga Pajak Penjualan Atas Barang Mewah. Salah satu ketentuan pengelompokan pengenaan Pajak Penjualan Atas Barang Mewah adalah terhadap Kendaraan Bermotor.

Faktor eksternal penerimaan pajak dipengaruhi oleh keadaan ekonomi makro negara. Fluktuasi ekonomi makro dapat menimbulkan dampak buruk bagi kegiatan perekonomian. Jika fluktuasi ekonomi tersebut terus berlangsung maka akan dapat menurunkan daya beli konsumsi, investasi dan ekspor impor yang akan berdampak pula pada penerimaan PPN. Komponen variabel ekonomi makro yang berperan dalam hal ini seperti salah saatunya yakni Nilai Tukar Rupiah.

Variabel ekonomi makro diantaranya kondisi nilai tukar merupakan harga mata uang terhadap mata uang lainnya (Sukirno, 2011). Ketika nilai tukar mengalami depresiasi maka harga barang dalam negeri meningkat dan akan mempengaruhi konsumsi masyarakat. Keadaan tersebut secara langsung dapat berdampak pada turunnya penerimaan pajak atas konsumsi (Renata, 2016). Banyak dampak negatif jika hal ini terus berlangsung, diantaranya berdampak pada perusahaan dalam negeri yang dalam kegiatan usahanya melibatkan ekspor impor yang akan berlanjut pada harga jual akhir yang ditawarkan kepada konsumen akan semakin tinggi sehingga daya beli konsumen akan turun.

Fluktuasi nilai tukar rupiah terhadap dolar Amerika Serikat memiliki dampak pada semua sisi APBN, baik pendapatan negara, belanja negara, maupun pembiayaan anggaran. Perubahan tersebut terjadi terutama pada anggaran yang menggunakan mata uang dolar Amerika Serikat sebagai komponen penghitungan. Pada sisi pendapatan negara, fluktuasi nilai tukar rupiah antara lain akan memengaruhi penerimaan yang terkait dengan aktivitas perdagangan internasional seperti PPh pasal 22 impor, PPN dan PPnBM impor, bea masuk, dan bea keluar.

Perkembangan nilai tukar rupiah dari tahun 2015 - 2019 semakin melemah. Pada tahun 2015 nilai tukar rupiah terhadap USD Rp 12000/USD, sedangkan tahun 2016 nilai tukar rupiah 
Sitti Mispa ${ }^{\bowtie}$

Pengaruh Pajak Penjualan atas Barang Mewah dan Nilai Tukar Rupiah terhadap Penerimaan Pajak pada Kantor Pelayanan Pajak Pratama Makassar Barat

DOI : https://doi.org/10.37531/ecotal.v2i2.26

terhadap USD melemah Rp 13500/USD dan pada menguat pada tahun 2018 nilai tukar rupiah terhadap USD Rp 15000/USD.

Berdasarkan penelitian yang dilakukan oleh (Karlina, 2016) tentang pengaruh pajak penjualan atas barang mewah (PPNBM) dan nilai tukar rupiah terhadap penerimaan pajak menyatakan bahwa secara simultan terdapat pengaruh antara PPnBM dan nilai tukar rupiah terhadap penerimaan pajak tahun 2010-2015 di KPP Madya Bandung. Sedangkan hasil analisis secara parsial didapat hasil bahwa PPnBM tidak berpengaruh signifikan terhadap penerimaan pajak dan nilai tukar rupiah berpengaruh secara signifikan terhadap penerimaan pajak.

Penelitian tersebut berbeda dengan penelitian (Sumidartini, 2017) yang menyatakan bahwa adanya pengaruh yang signifikan atas tingkat nilai tukar rupiah, dan tingkat suku bunga terhadap penerimaan pajak baik secara sendiri-sendiri (parsial) maupun secara bersama-sama (simultan). Hal ini menjelaskan bahwa semakin tinggi nilai tukar Rupiah, maka akan berdampak pada meningkatnya penerimaan pajak.

Dan dari hasil penelitian oleh (Geby Prisilia Iroth, 2016) menyatakan bahwa tingkat efektivitas pemungutan Pajak Penjualaan atas Barang Mewah sudah sangat efektif dengan persentase lebih dari $100 \%$, sistem dan prosedur yang diterapkan pada KPP Pratama Kotamobagu sudah berjalan dengan baik sesuai dengan peraturan Undang-Undang yang berlaku.

\section{Kajian Literatur}

\subsection{Definisi Pajak}

Merupakan iuran rakyat kepada kas negara dan merupakan kontribusi wajib kepada negara yang bersifat memaksa berdasarkan undang-undang dengan tidak mendapatkan imbalan secara langsung, tetapi digunakan untuk pengeluaran-pengeluaran negara dan sebesar-besarnya kemakmuran rakyat secara umum. Pajak merupakan iuran wajib rakyat kepada negara. Hasil pajak ini yang mana akan digunakan untuk membiayai kegiatan pemerintah sendiri (Alisman, Irwan Suharmi \& Fitri Nurhayani, 2018). Jadi, dapat disimpulkan bahwa pajak adalah iuran kepada Negara (yang dapat dipaksakan) yang terutang oleh yang wajib membayarnya menurut peraturan-peraturan dan tidak mendapatkan prestasi-prestasi kembali yang secara langsung dapat ditunjuk (https://eprints.uny.ac.id/7889/3/BAB\%202-09409134015.pdf). 


\subsection{Penerimaan Pajak}

Penerimaan pajak merupakan jumlah kontribusi masyarakat (yang dipungut berdasarkan undang-undang) yang diterima oleh negara dalam suatu masa yang akan digunakan untuk keperluan negara bagai sebesar-besarnya kemakmuran rakyat. Penerimaan pajak ini merupakan salah satu sumber untuk membiayai pengeluaran-pengeluaran negara yang pada masa mendatang diharapkan kontribusinya semakin meningkat agar tercapai kemandirian dalam pembiayaan negara (M. Yus Iqbal dkk, 2008)

\subsection{Pajak Penjualan Atas Barang Mewah}

Pajak Penjualan atas Barang Mewah (PPnBM) adalah pajak yang dipungut atas penyerahan Barang Kena Pajak (BKP) yang tergolong sebagai barang mewah yang dilakukan oleh pengusaha yang menghasilkan Barang Kena Pajak yang tergolong mewah tersebut di dalam daerah Pabean dalam kegiatan usaha atau pekerjaannya, ataupun impor Barang Kena Pajak yang tergolong mewah. PPN di Indonesia mewajibkan Pengusaha Kena Pajak (PKP) untuk memungut PPN ketika melakukan penjualan atau penyerahan Barang Kena Pajak (BKP) atau Jasa Kena Pajak (JKP) (Retno Bunga Widowati, 2017). Dengan demikian, PPnBM yang sudah dibayar pada waktu perolehan atau impor Barang Kena Pajak yang tergolong mewah tersebut, tidak dapat dikreditkan dengan PPN maupun PPnBM yang dipungut. Atau dengan kata lain, PPnBM ini hanya dipungut satu kali saja.

\subsection{Nilai Tukar Rupiah}

Banyaknya rupiah yang dibutuhkan untuk memperoleh satu unit mata uang asing. Di dalam perdagangan internasional terdapat perbedaan mata uang yang digunakan untuk melakukan transaksi (Desy Purwanti, 2018). Perubahan perilaku nilai tukar rupiah terhadap dolar AS banyak dipengaruhi oleh banyak faktor baik faktor fundamental maupun non fundamental (Samsul Arifin \& Shany Mayasya, 2018). Berdasarkan definisi - definisi tersebut dapat disimpulkan bahwa nilai tukar rupiah adalah rasio pertukaran anatara sejumlah mata uang domestik (rupiah) dengan satu unit mata uang asing.

\section{Gambar 1. Kerangka Konseptual}




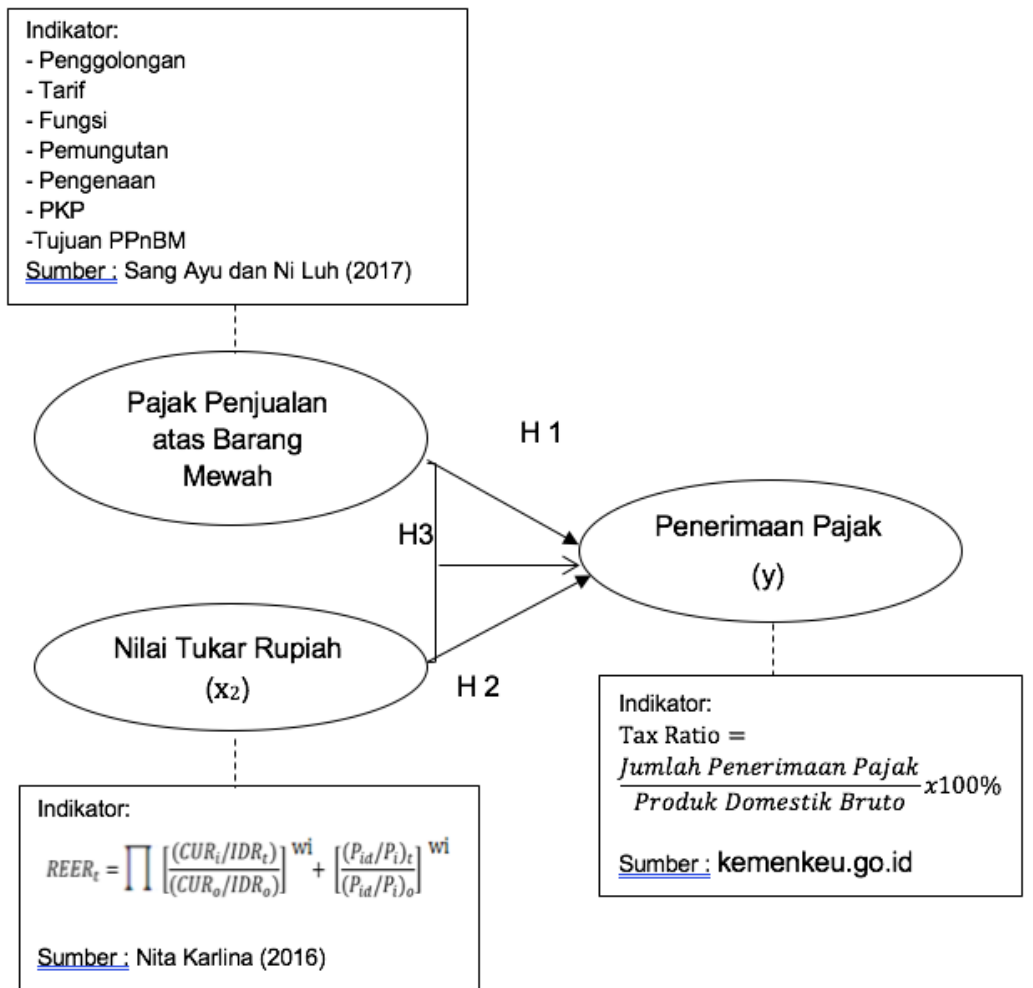

H1 : Pajak Penjualan atas Barang Mewah tidak berpengaruh positif terhadap Penerimaan Pajak

H2 : Nilai Tukar Rupiah berpengaruh positif terhadap Penerimaan Pajak

\section{Metode Penelitian}

Pendekatan dalam penelitian ini adalah pendekatan kuantitatif. Pendekatan kuantitatif adalah pendekatan kuantitatif merupakan penelitian yang menggunakan analisis data yang berbentuk numerik atau angka, Penelitian ini dilakukan pada Kantor Pelayanan Pajak Pratama Makassar Barat Jl. Balaikota No. 15, Baru, Kec. Ujung Pandang, Kota Makassar, Sulawesi selatan 90111 dan Badan Pusat Statistik Kota Makassar Jl. Prof. Abdurrahman Basalamah No. 1, Karampuang, Kec. Panakkukang, Kota Makassar, Sulawesi Selatan 90231. Waktu yang digunakan untuk penelitian ini yaitu terhitung sejak bulan September sampai Oktober 2020, Data penelitian ini berupa time series dalam kurun waktu 2015 - 2019 dengan data bulanan maka jumlah sampelnya sebanyak 60 pengamatan.

\section{Hasil Penelitian \& Pembahasan}

\subsection{Analisis Statistik Deskiptif}


Sitti Mispa ${ }^{\bowtie}$

Pengaruh Pajak Penjualan atas Barang Mewah dan Nilai Tukar Rupiah terhadap Penerimaan Pajak pada Kantor Pelayanan Pajak Pratama Makassar Barat

DOI : https://doi.org/10.37531/ecotal.v2i2.26

Statistik deskriptif berfungsi sebagai penganalisa data dengan menggambarkan sampel data yang telah dikumpulkan. Penelitian ini menjabarkan rata-rata (mean), nilai maksimum, nilai minimum dan standar deviasi dari masing-masing variabel sehingga secara kontekstual dapat lebih mudah dimengerti. Variabel yang digunakan dalam penelitian ini adalah variabel dependen dan independen. Variabel dependen dalam penelitian ini adalah penerimaan pajak sedangkan variabel independen dalam penelitian ini adalah pajak penjualan atas barang mewah dan nilai tukar rupiah.

Tabel 1. Hasil analisis deskriptif

Descriptive Statistics

\begin{tabular}{llllll}
\hline & N & Minimum & Maximum & Mean & Std. Deviation \\
\hline Ppnbm & 60 & 24.08 & 24.73 & 24.3112 & .14326 \\
\hline Nilai tukar rupiah & 60 & 9.45 & 9.63 & 9.5205 & .03998 \\
\hline Penerimaan pajak & 60 & 24.66 & 25.32 & 25.0922 & .15625 \\
\hline Valid N (listwise) & 60 & & & & \\
\hline
\end{tabular}

Sumber : Output spss 22 diolah (2020)

Diatas menunjukkan hasil statistik deskriptif sampel penelitian dari tahun 2015-2019 dengan jumlah sampel sebanyak 60 observasi. Berdasarkan pengujian yang telah dilakukan tersebut maka diperoleh penjelasan sebagai berikut untuk masing-masing variabel :

1) PPnBM

Pajak Penjualan atas Barang Mewah (PPnBM) adalah pajak yang dipungut atas penyerahan Barang Kena Pajak (BKP) yang tergolong sebagai barang mewah yang dilakukan oleh pengusaha yang menghasilkan Barang Kena Pajak yang tergolong mewah tersebut di dalam daerah Pabean dalam kegiatan usaha atau pekerjaannya, ataupun impor Barang Kena Pajak yang tergolong mewah. Indikator yang digunakan dalam variabel Ppnbm adalah penggolongan, tarif, fungsi, pemungutan, pengenaan, PKP, tujuan PPnBM. Berdasarkan hasil pengujian yang tampak pada tabel 4.7 tersebut diketahui bahwa nilai PpnBM dari sampel memiliki nilai minimum yaitu sebesar 24,08 dan nilai maksimum sebesar 24,73. Hasil tersebut menunjukkan bahwa 
besarnya PPnBM yang menjadi sampel dalam penelitian ini berkisar antara 24,08 hingga 24,73 dengan nilai mean 24,3112 dan standar deviasi 0,14326.

2) Nilai Tukar Rupiah

Nilai tukar rupiah merupakan rasio pertukaran antara sejumlah mata uang domestik (rupiah) dengan satu unit mata uang asing. Indikator yang digunakan nilai tukar rupiah adalah Nilai Tukar Riil atau Real Effective Exchange Rates (REER). Real Effective Exchange Rates (REER). Berdasarkan hasil pengujian yang tampak pada tabel 4.7 tersebut diketahui bahwa nilai tukar rupiah dari sampel memiliki nilai minimum yaitu sebesar 9,45 dan nilai maksimum sebesar 9,63. Hasil tersebut menunjukkan bahwa besarnya nilai tukar rupiah yang menjadi sampel dalam penelitian ini berkisar antara 9,45 hingga 9,63 dengan nilai mean 9,5205 dan standar deviasi 0,3998.

3) Penerimaan Pajak

Penerimaan pajak adalah rasio yang menunjukkan besarnya laba yang diperoleh sebuah perusahaan dalam periode tertentu. Indikator yang digunakan dalam variabel penerimaan pajak adalah Tax Ratio. Tax Ratio adalah perbandingan penerimaan pajak terhadap produk domestik bruto. Rasio ini merupakan alat ukur untuk menilai kinerja penerimaan pajak suatu Negara. Berdasarkan hasil pengujian yang tampak pada tabel 4.7 tersebut diketahui bahwa nilai penerimaan pajak dari sampel memiliki nilai minimum yaitu sebesar 24,66 dan nilai maksimum sebesar 25,32 Hasil tersebut menunjukkan bahwa besarnya penerimaan pajak yang menjadi sampel dalam penelitian ini berkisar antara 24,66 hingga 25,32 dengan nilai mean 25, 0922 dan standar deviasi 0,15625

b. Analisis Regresi Linear Berganda

Hasil regresi linear berganda berdasarkan pengolahan data menggunakan SPSS adalah sebagai berikut:

Tabel 2. Hasil analisis regresi linear berganda

\section{Coefficients $^{\mathrm{a}}$}




\begin{tabular}{|c|c|c|c|}
\hline \multirow[t]{2}{*}{ Model } & & \multicolumn{2}{|c|}{$\begin{array}{l}\text { Unstandardized } \\
\text { Coefficients }\end{array}$} \\
\hline & & B & Std. Error \\
\hline \multirow[t]{3}{*}{1} & (Constant) & 5.472 & 4.301 \\
\hline & ppnbm & .416 & .136 \\
\hline & Nilai tukar rupiah & .999 & .486 \\
\hline
\end{tabular}

Sumber: Output spss 22 diolah (2020)

Dapat dirumuskan suatu persamaan regresi untuk mengetahui pengaruh ppnbm dan nilai tukar rupiah terhadap penerimaan pajak adalah sebagi berikut:

$$
Y=5,472+0,416 X_{1}+0,999 X_{2}
$$

Model ini menunjukkan bahwa koefisien regresi hasil taksiran X1 dan X2 bertanda positif. Hasil ini memberikan gambaran bahwa adanya hubungan positif dari variabel PPnBM dan nilai tukar rupiah terhadap penerimaan pajak, yang berarti bahwa semakin meningkatnya PPnBM dan nilai tukar rupiah maka akan meningkatkan penerimaan pajak.

Dapat dijelaskan variabel PPnBM (X1) memiliki koefisien regresi positif sebesar 0,416, berarti apabila PPnBM naik sebesar 1\% maka penerimaan pajak akan mengalami kenaikan sebesar $0,416 \%$ pada saat variabel bebas lainnya tidak berubah (konstan). Variabel nilai tukar rupiah (X2) memiliki koefisien regresi positif sebesar 0,999, berarti apabila nilai tukar rupiah naik sebesar 1\% maka penerimaan pajak akan mengalami kenaikan sebesar 0,999\% pada saat variabel bebas lainnya tidak berubah (konstan). Koefisien regresi linear berganda untuk konstan sebesar 5,472, artinya pada saat variabel ppnbm dan nilai tukar rupiah sama dengan nol maka besarnya penerimaan pajak 5,472

\subsection{Hasil Pengujian Hipotesis}

a. Hasil Pengujian Simultan (Uji F)

Uji F digunakan untuk menguji pengaruh variabel independen yang terdiri dari PPnBM (X1) dan nilai tukar rupiah (X2) secara simultan atau bersama-sama. Berikut adalah tabel hasil pengujian simultan penelitian :

Tabel 2. Hasil uji simultan 


\begin{tabular}{|c|c|c|c|c|c|c|}
\hline \multicolumn{7}{|c|}{ ANOVA ${ }^{a}$} \\
\hline & Model & Sum of & $\mathrm{df}$ & Mean Square & $\mathrm{F}$ & Sig. \\
\hline \multirow[t]{3}{*}{1} & Regression & .430 & 2 & .215 & 12.136 & $.000^{\mathrm{b}}$ \\
\hline & Residual & 1.010 & 57 & .018 & & \\
\hline & Total & 1.440 & 59 & & & \\
\hline
\end{tabular}

a. Dependent Variable: penerimaan pajak

b. Predictors: (Constant), nilai tukar rupiah, PPnBM

Sumber : Output spss 22 diolah (2020)

Hasil perhitungan $F_{\text {tabel }}$ dengan nilai signifikansi 0.05 adalah 3,159. Hasil pengujian ANOVA dengan menggunakan uji $\mathrm{F}$ dapat dilihat dari nilai $\mathrm{F}_{\text {hitung }}$ sebesar 12,136 dan nilai $\mathrm{F}_{\text {tabel }}$ 3,159. Dengan kondisi dimana $\mathrm{F}_{\text {hitung }}$ lebih besar daripada $\mathrm{F}_{\text {tabel }}$ dan dengan nilai signifikansi sebesar $0,000<0,05$ artinya signifikan. Maka dapat disimpulkan bahwa PPnBM (X1) dan nilai tukar rupiah (X2) berpengaruh positif signifikan terhadap penerimaan pajak (Y), atau dengan kata lain $\mathrm{H}_{0} 1$ ditolak dan $\mathrm{H}_{\mathrm{a}} 1$ diterima, hipotesis diterima.

b. Hasil Pengujian Parsial (Uji t)

Uji t bertujuan untuk mengetahui pengaruh variabel independen yang terdiri dari PPnBM (X1) dan nilai tukar rupiah (X2) berpengaruh secara parsial terhadap penerimaan pajak (Y). Berikut adalah tabel hasil pengujian parsial penelitian.

Tabel 3. Hasil uji parsiaL

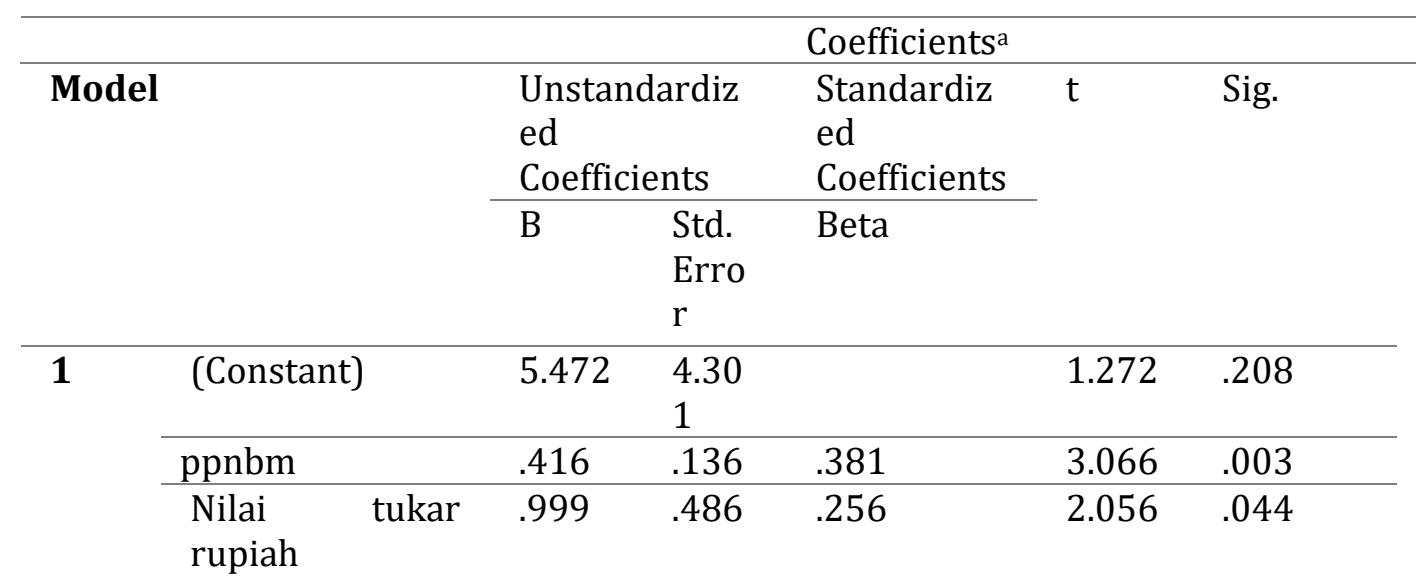

a. Dependent Variable: penerimaan pajak

Sumber : Output spss 22 diolah (2020) 
Dapat diketahui pengaruh masing-masing variabel independen yang terdiri atas PPnBM dan nilai tukar rupiah terhadap variabel dependen yaitu penerimaan pajak dijelaskan sebagai berikut :

Hasil perhitungan $t_{\text {tabel }}$ dengan nilai signifikansi 0.05 didapatkan nilai sebesar 2,001. Hasil penelitian PPnBM (X1) terhadap penerimaan pajak (Y) diperoleh data yakni $t_{\text {hitung }}=3,066$ dan $t_{\text {tabel }}=2,018$. Tampak bahwa untuk variabel PPnBM (X1), $t_{\text {hitung }}>t_{\text {tabel. }}$ Dan dengan nilai signifikansi sebesar $0.003<0.05$. Maka dapat disimpulkan bahwa PPnBM (X1) berpengaruh positif signifikan terhadap penerimaan pajak (Y), atau dengan kata lain $\mathrm{H}_{0} 2$ ditolak dan $\mathrm{H}_{\mathrm{a}} 2$ diterima, hipotesis diterima.

Hasil penelitian nilai tukar rupiah (X2) terhadap penerimaan pajak (Y) diperoleh data yakni $t_{\text {hitung }}=2,056$ dan $t_{\text {tabel }}=2,001$. Tampak bahwa untuk variabel nilai tukar rupiah (X2) $t_{\text {hitung }}>t_{\text {tabel }}$. Dan dengan nilai signifikansi sebesar 0,044 $<0.05$ artinya signifikan. Maka dapat disimpulkan bahwa PPnBM (X1) berpengaruh positif signifikan terhadap penerimaan pajak (Y), atau dengan kata lain $\mathrm{H}_{0} 2$ ditolak dan $\mathrm{H}_{\mathrm{a}} 2$ diterima, hipotesis diterima.

c. Uji Koefisien Determinasi $\left(\mathrm{R}^{2}\right)$

Uji koefisien determinasi digunakan untuk menerangkan seberapa besar presentase variabel independen mampu menjelaskan variabel dependen. Nilai $\mathrm{R}^{2}$ yang semakin mendekati angka 1 menunjukkan bahwa pengaruh variabel independen terhadap variabel dependen semakin besar. Hasil uji $\mathrm{R}^{2}$ dapat dilihat pada tabel berikut :

Tabel 4. Hasil uji koefisien determinasi $\left(\mathrm{R}^{2}\right)$

\begin{tabular}{ccccr}
\hline \multicolumn{4}{c}{ Model Summary } \\
\hline $\begin{array}{c}\text { Mod } \\
\text { el }\end{array}$ & $\mathrm{R}$ & $\mathrm{R}$ & Adjusted R & $\begin{array}{r}\text { Std. Error of } \\
\text { the Estimate }\end{array}$
\end{tabular}

$\begin{array}{lllll} & .546^{\mathrm{a}} & .299 & .274 & .13313\end{array}$

a. Predictors: (Constant), nilai tukar rupiah, ppnbm

Sumber : Output spss 22 diolah (2020) 
Sitti Mispa ${ }^{\bowtie}$

Pengaruh Pajak Penjualan atas Barang Mewah dan Nilai Tukar Rupiah terhadap Penerimaan Pajak pada Kantor

Pelayanan Pajak Pratama Makassar Barat

DOI : https://doi.org/10.37531/ecotal.v2i2.26

Menunjukkan hasil $\mathrm{R}^{2}$ yaitu sebesar 0,299 atau 29,9\%\% besarnya penerimaan pajak yang dipengaruhi oleh variabel ppnbm dan variabelnilai tukar rupiah. Sedangkan 70,1\% penerimaan pajak dipengaruhi oleh variabel diluar penelitian yang dilakukan.

\subsection{Interpretasi Hasil Penelitian}

a. Pengaruh pajak penjualan atas barang mewah terhadap penerimaan pajak

Menurut Undang-undang PPN No 42 Tahun 2009, pengertian Pajak Penjualan atas Barang Mewah (PPnBM) adalah pajak yang dipungut atas penyerahan Barang Kena Pajak (BKP) yang tergolong sebagai barang mewah yang dilakukan oleh pengusaha yang menghasilkan Barang Kena Pajak yang tergolong mewah tersebut di dalam daerah pabean dalam kegiatan usaha atau pekerjaannya, ataupun impor Barang Kena Pajak yang tergolong mewah.

Berdasarkan hasil analisis regresi linear berganda yang telah dilakukan untuk menunjukkan bahwa PPnBM memiliki pengaruh yang searah (positif) terhadap penerimaan pajak pada kantor pelayanan pajak pratama Makassar Barat, yang berarti bahwa semakin meningkatnya penerimaan PPnBM maka akan meningkatkan penerimaan pajak, begitu pula sebaliknya. perbedaan pembebanan pajak penjualan menyebabkan pajak penjualan lebih banyak dikumpulkan dari kegiatan impor dibandingkan dari kegiatan domestik, sehingga akan mempengaruhi total penerimaan pajak. Dengan kondisi masyarakat yang cenderung konsumtif pajak penjualan barang mewah sejauh ini mendominasi penerimaan pajak dan menjadikan penerimaan PPnBM meningkat selama empat tahun terakhir. Namun dapat disimpulkan bahwa secara parsial tidak terdapat pengaruh signifikan dari Penerimaan PPnBM (X1) terhadap Realisasi Penerimaan Pajak (Y). Hasil penelitian ini sejalan dengan penelitian yang dilakukan oleh Nita Karlina, dkk (2016) yang menyatakan bahwa hasil analisis secara parsial didapat hasil bahwa PPnBM tidak berpengaruh signifikan terhadap penerimaan pajak.

b. Nilai tukar rupiah terhadap penerimaan pajak

Nilai tukar rupiah adalah rasio pertukaran antara sejumlah mata uang domestik (rupiah) dengan satu unit mata uang asing. Berdasarkan hasil analisis linear berganda yang telah dilakukan untuk menunjukkan bahwa nilai tukar rupiah memiliki pengaruh yang searah (positif) terhadap penerimaan pajak, yang berarti bahwa semakin meningkatnya nilai tukar rupiah maka akan meningkatkan penerimaan pajak, begitu pula sebaliknya. Dengan melihat kondisi ekonomi pada

Volume 2 Issue 1 (2021)

Economics and Digital Business Review

ISSN: 2774-2563 (Online) 
Sitti Mispa ${ }^{\bowtie}$

Pengaruh Pajak Penjualan atas Barang Mewah dan Nilai Tukar Rupiah terhadap Penerimaan Pajak pada Kantor Pelayanan Pajak Pratama Makassar Barat

DOI : $\underline{\text { https://doi.org/10.37531/ecotal.v2i2.26 }}$

tahun 2015 dimana Indonesia banyak melakukan transaksi dengan negara luar, maka nilai tukar rupiah sebagai mediator perdagangan akan mempengaruhi penerimaan negara yang tidak terlepas dari penerimaan pajak yang mendominasi penerimaan negara selama beberapa tahun terakhir. Namun dapat disimpulkan bahwa secara parsial nilai tukar rupiah berpengaruh signifikan terhadap penerimaan pajak. Hasil penelitian ini sejalan dengan penelitian yang dilakukan oleh Nita Karlina, dkk (2016) yang menyatakan bahwa hasil analisis secara parsial didapat hasil bahwa nilai tukar rupiah berpengaruh signifikan terhadap penerimaan pajak.

c. Pajak penjualan atas barang mewah dan nilai tukar rupiah terhadap penerimaan pajak

Berdasarkan hasil analisis regresi linear berganda yang telah dilakukan untuk menunjukkan bahwa ppnbm dan nilai tukar rupiah memiliki pengaruh yang searah (positif) terhadap penerimaan pajak pada kantor pelayanan pajak pratama Makassar Barat, yang berarti bahwa semakin meningkatnya penerimaan PPnBM maka akan meningkatkan penerimaan pajak, begitu pula sebaliknya. Dapat disimpulkan bahwa pajak penjualan atas barang mewah dan nilai tukar rupiah secara simultan atau bersama-sama berpengaruh terhadap penerimaan pajak. Hasil penelitian ini sejalan dengan penelitian yang dilakukan oleh Nita Karlina, dkk (2016) yang menyatakan bahwa hasil analisis secara simultan bahwa PPnBM dan nilai tukar rupiah berpengaruh terhadap penerimaan pajak.

\section{Kesimpulan}

Pajak penjualan atas barang mewah tidak berpengaruh positif dan signifikan terhadap penerimaan pajak, nilai tukar rupiah berpengaruh positif dan signifikan terhadap kebijakan penerimaan pajak, pajak penjualan atas barang mewah dan nilai tukar rupiah secara simultan berpengaruh positif signifikan terhadap penerimaan pajak pada kantor pelayanan pajak pratama Makassar Barat.

\section{Referensi :}

Karlina Nita, Dudi Pratomo, dan Annisa Nurbaiti. (2016). Pengaruh Pajak Penjualan Atas Barang Mewah (PPNBM) dan Nilai Tukar Rupiah Terhadap Penerimaan Pajak, (Studi Empiris pada Kantor Pelayanan Pajak (KPP) Madya Bandung tahun 2010-2015). e-Proceeding of Management. 3. (3): 3282-3291

Kementrian Keuangan Direktorat Jenderal Pajak. (2020). 86. Rasio Pajak (Tax Ratio) dari Masa ke Masa. https://www.pajak.go.id/id/86-rasio-pajak-tax-ratio-dari-masa-ke-masa Diakses pada 16 Juli 2020 
Kementrian Keuangan Republik Indonesia. (2015). Tugas dan Fungsi Penerimaan Pajak. https://www.kemenkeu.go.id/publikasi/berita/tugas-dan-fungsi-pen erimaan-pajak/ Diakses pada 16 Juli 2020

Kementrian Keuangan Republik Indonesia. (2019). Mengenal Rasio Pajak Indonesia. https://www.kemenkeu.go.id/publikasi/berita/mengenal-rasio-pajak-indonesia/ Diakses pada 16 Juli 2020

Renata, A. H., Hidayat, K., \& Kaniskha, B. (2016). Pengaruh Inflasi, Nilai Tukar Rupiah Dan Jumlah Pengusaha Kena Pajak Terhadap Penerimaan Pajak Pertambahan Nilai (Studi pada Kantor Wilayah DJP Jawa Timur I). Malang: Jurnal Perpajakan (JEJAK)| Vol. 9 No. 1.

Siti Resmi. (2011). Perpajakan Teori dan Kasus. Edisi 6, Buku 2. Jakarta: Salemba Empat

Sumidartini, Ai Nety. (2017). Pengaruh Nilai Tukar Rupiah Serta Tingkat Suku Bunga Terhadap Penerimaan Pajak Pada Direktorat Jenderal Pajak. Transparansi Jurnal Ilmiah Ilmu Administrasi. 9 (1): 53-68

Tirta Citradi, CNBC Indonesia. (2020). Penerimaan PPN, PPnBM \& PPh Migas Anjlok, Ini Penyebabnya. https://www.cnbcindonesia.com/news/2020010 8163243-4128631/penerimaan-ppn-ppnbm-pph-migas-anjlok-ini-penyebabnya Diakses pada 16 Juli 2020

Paramita, A.A Mirah Pradnya, Budiasih, I Gusti Ayu Nyoman(2015)Pengaruh Sistem Perpajakan, Keadilan, dan Teknologi Perpajakan pada Persepsi Wajib Pajak Mengenai Penggelapan Pajak. E-Jurnal Akuntansi Universitas Udayana. Xx. x.

Diky Budiman \& Septa Diana Nabella. Masuknya Warga Negara Asing dalam Perspektif Ekonomi Pertahanan. Jurnal Bening Prodi Manajemen Universitas Riau Kepulauan Batam, Volume 7 No. 1 Tahun 2020.

Gunawan, Andri \& Sukartha, I Made. Pengaruh Persepsitax Amnesty, Pertumbuhan Ekonomi dan Transformasi Kelembagaan Direktorat Jenderal Pajak Pada Penerimaan Pajak. E-Jurnal Akuntansi Universitas Udayana, Vol.17.3. Desember (2016): 2036-2060.

Puspareni, Kadek Diah, Purnamawai, I Gusti Ayu, Wahyuni, Made Arie. Pengaruh Tax Amnesty, Pertumbuhan Ekonomi, Kepatuhan Wajib Pajak, dan Transformasi Kelembagaan Direktorat Jenderal Pajak Terhadap Penerimaan Pajak Tahun Pajak 2015 di Kantor Pelayanan Pajak Pratama Singaraja. e-journal S1 Ak Universitas Pendidikan Ganesha Jurusan Akuntansi Program S1 (Volume 7 No.1 Tahun 2017).

Iqbal, M.Yus. dkk. Tinjauan Perencanaan Penerimaan Perpajakan dan Realisasinya. Biro Analisa Anggaran dan Pelaksanaan APBN Setjen DPR RI. https://www.dpr.go.id/doksetjen/dokumen/apbn_Tinjauan_penerimaan_perpajakan2 0130129122144.pdf

https://eprints.uny.ac.id/7889/3/BAB\%202-09409134015.pdf

Arifin, Samsul Arifin \& Shany Mayasya. Faktor - Faktor yang Mempengaruhi Nilai Tukar Rupiah terhadap Dolar Amerika Serikat. Jurnal Ekonomi-Qu, Vol. 8, No. 1, Apr 2018.

Desy Purwanti. (2018). Analisis Faktor-Faktor yang Mempengaruhi Nilai Tukar Rupiah terhadap Dolar Amerika Aplikasi Teori Purchasing Power Parity (PPP). http://eprints.ums.ac.id/61344/16/NASKAH\%20PUBLIKASI.pdf. Diakses 20 Februari 2021.

Alisman dkk (2018). Intensifikasi Dan Ekstensifikasi Penerimaan Pajak Daerah dalam Menunjang Pendapatan Asli Daerah (Pad) di Kabupaten Nagan Raya. Jurnal Ekombis, DOI: $10.35308 /$ ekombis.v4i2.1343 